\title{
PENGARUH MODEL PEMBELAJARAN KOOPERATIF TIPE TWO STAY TWO STRAY (TSTS) DAN ARTIKULASI TERHADAP HASIL BELAJAR SISWA PADA MATERI EKOSISTEM DI SMA NEGERI 1 SIBABANGUN KABUPATEN TAPANULI TENGAH
}

\author{
Muhammad Adlan Lubis (Mhdadlan77@gmail.com )
}

\begin{abstract}
ABSTRAK
Penelitian ini bertujuan untuk mengetahui pengaruh model pembelajaran kooperatif terhadap hasil belajar siswa pada materi ekosistem di kelas X SMA Negeri 1 Sibabangun. Metode penelitian menggunakan eksperimen semu dengan sampel penelitian sebanyak 3 kelas ditentukan secara acak dengan teknik cluster random sampling. Kelas A dibelajarkan dengan model pembelajaran two stay two stray (TSTS), kelas $B$ dengan model pembelajaran artikulasi dan kelas $C$ (kontrol) dengan pembelajaran konvensional. Instrumen penelitian menggunakan tes hasil belajar dalam bentuk pilihan berganda. Teknik analisis data untuk hasil belajar menggunakan Analisis Kovarians (ANAKOVA) pada taraf signifikan $\alpha=0,05$ dengan bantuan SPSS 21.0. Hasil penelitian menunjukkan ada pengaruh signifikan model pembelajaran TSTS $(84,71 \pm 14,729) ;$ artikulasi $(82,29 \pm 15,942)$, dan konvensional $(50,70 \pm 23,628)$ terhadap hasil belajar siswa. Berdasarkan data hasil penelitian dapat disimpulkan bahwa hasil belajar siswa yang dibelajarkan dengan model pembelajaran TSTS dan artikulasi lebih tinggi dibandingkan dengan konvensional.
\end{abstract}

Kata Kunci: Hasil Belajar, TSTS, Artikulasi.

\begin{abstract}
The aims of this research were to examine the effect of cooperative learning model on students' learning outcomes in ecosystem topic in grade X SMA Negeri 1 Sibabangun. This quasy experimental research were used 3 classes as the sample of research which taken by cluster random sampling technique. The A class was taught with two stay two stray (TSTS) learning models, the B class was treated with articulation learning model, and the $C$ class was taught with conventional learning model. The research instrument were the learning outcomes test in multiple choice design. The data of learning outcomes were analyzed by Analysis Of Covariance $t \alpha=0,05$ with SPSS 21.0. The result showed there was significant effect of TSTS $(84,71 \pm 14,729)$; articulation $(82,29 \pm 15,942)$, and conventional $(50,70 \pm 23,628)$ learning model on students' learning outcomes. Based on the research findings it wa s concluded that students' learning outcomes which taught by TSTS and articulation were score higher than conventional learning model.
\end{abstract}

Keywords: Learning outcomes, TSTS, Articulation.

\section{PENDAHULUAN}

Pendidikan adalah usaha sadar dan terencana untuk mewujudkan suasana belajar dan proses pembelajaran agar peserta didik secara aktif mengembangkan potensi dirinya untuk memiliki kekuatan spiritual keagamaan, pengendalian diri, kepribadian, kecerdasan, akhlak mulia serta keterampilan yang diperlukan dirinya, masyarakat, bangsa dan negara (Pasal 1 ayat 1 UU Sistem Pendidikan Nasional Nomor 20 Tahun 2003).

Peningkatan mutu pendidikan merupakan salah satu program pembangunan nasional yang erat sekali hubungannya dengan pengembangan sumber daya manusia. Salah satu usaha dalam peningkatan mutu pendidikan adalah dengan meningkatkan proses belajar melalui strategi, metode maupun model pembelajaran yang sesuai dengan materi ajar. Kualitas hasil belajar terutama terletak ditangan guru yang berkualitas pula, keberhasilan suatu pengajaran sangat dipengaruhi oleh proses belajar mengajar yang di laksanakan dan dikelola oleh guru yang profesional.

Semakin tinggi tingkat kualitas guru dalam memahami proses dan mengelola proses pembelajaran, semakin tinggi pula tingkat pemahaman siswa terhadap materi yang disajikan. Bahan atau materi pelajaran (learning materials) adalah segala sesuatu yang menjadi isi kurikulum yang harus dikuasai oleh siswa sesuai dengan kompetensi dasar dalam rangka pencapaian 
JURNAL BIOLOKUS Vol.1 (2)

standar kompetensi setiap mata pelajaran dalam satuan pendidikan tertentu (Sanjaya, 2012).

\section{MODEL TWO STAY TWO STRAY (TSTS)}

Model Two Stay Two Stray (TSTS) atau dua tinggal dua bertamu adalah model yang dikembangkan oleh Spencer Kagan, dua tinggal dua tamu memberi kesempatan kepada kelompok untuk membagikan hasil dan informasi dengan kelompok lain (Putra, 2014). Menurut Shoimin (2014), menjelaskan langkah-langkah model pembelajaran kooperatif Tipe Two Stay Two Stray sebagai berikut : 1) siswa bekerja sama dalam kelompok berempat seoperti biasa; 2) setelah selesai dua siswa dari masing-masing kelompok akan meninggalkan kelompoknya yang lain; 3) dua siswa yang tinggal dalam kelompok bertugas membagikan hasil kerja dan informasi mereka kepada tamu mereka; 4) tamu mohon diri dan kembali pada kelompok mereka sendiri dan melaporkan temuan mereka dalam kelompok lain; 5) kelompok mencocokan dan membahas hasil kerja mereka.

\section{MODEL ARTIKULASI}

Menurut Wenger dalam Silvia (2012), artikulasi didefinisikan sebagai struktur-struktur dalam otak yang melibatkan kemampuan berbicara dan memprosesan kata lainnya dan area tambahan menulis, membuat sketsa dan lain-lain. Model pembelajaran artikulasi yaitu model dimana siswa membentuk kelompok berpasangan dua orang, salah seorang menceritakan materi yang telah dijelaskan oleh guru dan pasanganya berperan sebagai pendengar kemudian berganti peran setelah siswa diacak kedepan bersama pasangannya untuk menyampaikan hasil wawancaranya sampai sebahagian siswa sudah menyampaikan hasil wawancara kemudian guru menjelaskan kembali materi yang belum dipahami oleh siswa. Dengan model pembelajaran artikulasi siswa dilatih untuk bisa menjelaskan kembali apa yang dijelaskan guru sehingga siswa bisa mengetahui sampai dimana pemahaman siswa terhadap materi yang diberikan serta mengulangi kembali materi yang belum dikuasai siswa (Rahmadini, 2013).

Dari hasil observasi beberapa guru bidang studi biologi yang dilakukan peneliti, mengemukakan bahwa guru bidang studi biologi, dalam proses belajar mengajar lebih sering menggunakan pembelajaran konvensional sehingga proses belajar mengajar dalam kelas kurang aktif dan siswa cenderung hanya mendengarkan penjelasan guru dan proses pembelajaran juga berpusat pada guru.

Berdasarkan hasil observasi tersebut, maka peneliti juga menemukan hal yang sama di SMA Negeri 1 Sibabangun dari hasil wawancara, diketahui berdasarkan hasil data kumpulan nilai (DKN) yang diperoleh dari guru bidang studi biologi SMA Negeri 1 Sibabangun dapat disimpulkan bahwa hasil belajar siswa masih rendah dan terdapat beberapa siswa yang masih memperoleh nilai di bawah kriteria ketuntasan minimum (KKM) yaitu 70, hal ini sesuai dengan yang di sampaikan oleh guru SMA Negeri 1 Sibabangun, masih banyaknya siswa yang kurang mengerti dengan pembelajaran yang disampaikan oleh guru karena siswa kurang termotivasi dengan cara pembelajaran konvensional, siswa kurang berperan aktif dalam proses belajar mengajar di dalam kelas ditunjukkan dengan kurangnya rasa ingin tahu siswa terhadap materi pelajaran dan pembelajaran yang dilakukan guru pada umumnya masih menggunakan pembelajaran konvensional. Untuk dapat melibatkan siswa aktif dalam proses belajar mengajar di kelas dan mampu meningkatkan hasil belajar siswa diperlukan suatu model pembelajaran yang tepat, salah satunya adalah model pembelajaran kooperatif.

Observasi yang dilakukan Wardhani (2012), menyebutkan bahwa guru memberikan materi pelajaran dengan ceramah, kadang diselingi tanya jawab dengan siswa, dan menggunakan media powerpoint sehingga proses pembelajaran masih berpusat pada guru dan kurang memberikan kesempatan pada siswa untuk terlibat aktif di dalam proses pembelajaran, dan guru belum menerapkan model pembelajaran yang sesuai. Setelah melakukan penelitianan dengan menerapkan model kooperatif tipe Two Stay Two Stray (TSTS) dan memberikan hasil bahwa, model kooperatif tipe TSTS mampu meningkatkan kualitas pembelajaran biologi siswa.

Handayani (2014), mengatakan bahwa hasil observasi yang dilakukan, proses pembelajaran masih di dominasi guru, pada saat pembelajaran siswa menampakkan sikap kurang bergairah, kurang bersemangat, kurang siap mengikuti pembelajaran, suasana kurang aktif, interaksi 
antara guru dengan siswa sangat kurang, apalagi siswa dengan siswa cenderung pasif dan hanya menerima apa saja yang diberikan guru, motivasi belajar siswa masih rendah. Setelah melakukan penelitian dengan menerapkan model kooperatif tipe TSTS, maka hasil belajar siswa lebih baik daripada pembelajaran konvensional.

Survei awal yang dilakukan Leluhur (2009), bahwa prestasi belajar siswa masih rendah dan model pembelajaran yang digunakan guru adalah model pembelajaran konvensional dan proses pembelajaran yang masih berpusat pada guru dan dengan dilakukannya penelitian menggunakan model pembelajaran kooperatif tipe artikulasi maka di dapatkkan hasil bahwa model ini dapat meningkatkan aktivitas siswa dan meningkatkan prestasi belajar. Hasil observasi yang dilakukan oleh Rachmawan (2013), menyatakan bahwa proses belajar mengajar dalam kelas guru menggunakan pembelajaran langsung yang disertai tanya jawab dan penugasan secara individu, disebutkan bahwa pembelajaran langsung sebenarnya baik namun dibutuhkan penyempurnaan pada model pembelajaran yang lebih baik, setelah dilakukan penelitian dengan menggunakan model pembelajaran kooperatif tipe artikulasi hasil belajar siswa dan keterampilan sosial siswa meningkat.

Dari beberapa hasil penelitian di atas maka model pembelajaran kooperatif tipe TSTS dan Artikulasi diharapkan dapat meningkatkan hasil belajar siswa SMA Negeri 1 Sibabangun.

\section{METODE PENELITIAN}

Populasi dalam penelitian ini adalah seluruh siswa kelas X SMA Negeri 1 Sibabangun, seluruhnya berasal dari 5 kelas. Teknik pengambilan sampel dalam penelitian ini adalah cluster random sampling (sampel acak berkelompok). Pengacakan dilakukan dengan cara undian kelas dan dari hasil pengundian diperoleh kelas $\mathrm{X}_{1}$ berjumlah 37 siswa, diberikan perlakuan dengan pembelajaran konvensional, kelas $X_{2}$ berjumlah 28 siswa sebagai kelas eksperimen pertama dibelajarkan dengan model pembelajaran artikulasi dan kelas $\mathrm{X}_{3}$ berjumlah 28 siswa sebagai kelas eksperimen kedua yang dibelajarkan dengan model pembelajaran Two Stay Two Stray (TSTS).

Adapun rancangan penelitian yang digunakan rancangan eksperimen semu (quasi experiment research) dengan pretest-postest control group design, terdapat pada tabel 1.

Tabel 1. Pretest-Postest Control Group Design.

\begin{tabular}{cccc}
\hline Kelas & Pretes & Perlakuan & Postes \\
\hline A & $\mathrm{T}_{1}$ & $\mathrm{X}_{1}$ & $\mathrm{~T}_{1}$ \\
B & $\mathrm{T}_{2}$ & $\mathrm{X}_{2}$ & $\mathrm{~T}_{2}$ \\
C & $\mathrm{T}_{3}$ & $\mathrm{X}_{3}$ & $\mathrm{~T}_{3}$ \\
\hline
\end{tabular}

Keterangan :

X1 :Perlakuan dengan menggunakan pembelajaran konvensional

X2 :Perlakuan dengan menggunakan model pembelajaran artikulasi.

X3 :Perlakuan dengan menggunakan model pembelajaran Two Stay Two Stray (TSTS)

T1 : Pretes hasil belajar

T2 : Postes hasil belajar.

Hasil belajar diperoleh dari instrumen tes hasil belajar berupa bilihan berganda (multiple choise). Teknik analisis data berupa analisis inferensial. Sebelum pengujian hipotesis terlebih dahulu dilakukan uji prasyarat terhadap data yang dikumpulkan yaitu dengan menggunakan uji normalitas dan homogenitas. Uji normalitas menggunakan Kolmogorov-Smirnov, sedangkan uji homogenitas menggunakan Levene's Test. Pengujian hipotesis data hasil belajar dilakukan dengan menggunakan Analisis Kovariat (ANAKOVA). Apabila hasil uji statistik menunjukkan pengaruh yang signifikan, maka analisis dilanjutkan dengan uji Tukey's. Pengolahan data dilakukan dengan menggunakan SPSS.21.0.

\section{HASIL dan PEMBAHASAN \\ Hasil Belajar Siswa}

Hasil penelitian ini menunjukkan bahwa analisis data hasil belajar siswa berpengaruh signifikan, dimana hasil belajar siswa yang dibelajarkan dengan menggunakan model pembelajaran Two Stay Two Stray (TSTS) memiliki sebaran data yang terdistribusi normal $(\mathrm{Z}=1,098 ; \mathrm{P}=0,179)$, hasil belajar siswa yang dibelajarkan dengan menggunakan model pembelajaran atrikulasi memiliki sebaran data yang terdistribusi normal $(\mathrm{Z}=0,859 ; \mathrm{P}=0,452)$ dan pada kelas konvensional memiliki sebaran data yang terdistribusi normal $(\mathrm{Z}=0,816$; $\mathrm{P}=0,518$ ) atau memenuhi prasyarat uji normalitas dan pengujian hipotesis dan hasil uji homogenitas menunjukkan variasi data antara ketiga kelompok 
JURNAL BIOLOKUS Vol.1 (2)

sampel dalam populasi adalah homogen $(\mathrm{F}=2,972$; $\mathrm{P}=0,56)$.

\section{PENGUJIAN HIPOTESIS.}

Pengaruh Model Pembelajaran terhadap Hasil Belajar Siswa

Hasil uji hipotesis Analisis Kovariat (ANAKOVA) memperlihatkan bahwa model pembelajaran berpengaruh secara signifikan terhadap hasil belajar siswa dengan nilai postest $(\mathrm{F}=37,993 ; \mathrm{P}=0,000)$, mengindikasikan bahwa hasil belajar siswa juga dipengaruhi oleh kemampuan awal (pretest) siswa sebelum diberikan model pembelajaran.

Maka secara keseluruhan terdapat pengaruh yang signifikan rata-rata hasil belajar siswa yang dibelajarkan dengan model pembelajaran kooperatif tipe TSTS, artikulasi dan konvensional, sehingga $\mathrm{H}_{0}$ yang menyatakan bahwa tidak terdapat pengaruh model pembelajaran TSTS dan artikulasi terhadap hasil belajar siswa kelas X pada materi ekosistem di SMA Negeri 1 Sibabangun Kabupaten Tapanuli Tengah ditolak dan $\mathrm{H}_{a}$ terdapat pengaruh model pembelajaran TSTS dan artikulasi terhadap hasil belajar siswa kelas X pada materi ekosistem di SMA Negeri 1 Sibabangun Kabupaten Tapanuli Tengah diterima.

Hasil uji Tukey's menunjukkan bahwa hasil belajar siswa yang dibelajarkan dengan model pembelajaran TSTS dengan \pm SD 84,71 $\pm 14,729$ lebih tinggi secara signifikan dibandingkan dengan hasil belajar siswa dari kelas yang dibelajarkan dengan model pembelajaran artikulasi dengan \pm SD $82,29 \pm 15,942$. Hasil belajar siswa yang dibelajarkan dengan model pembelajaran TSTS dan artikulasi lebih tinggi dibandingkan dengan kelas yang dibelajarkan dengan model pembelajaran konvensional dengan \pm SD 50,70 $\pm 23,628$ disajikan pada Gambar 1.

\section{PEMBAHASAN}

Hasil penelitian dan pengujian hipotesis menunjukkan bahwa adanya perbedaan yang signifikan antara kelas kontrol (konvensional) dan kelas eksperimen (TSTS dan artikulasi) pada hasil belajar siswa, dimana model pembelajaran kooperatif tipe TSTS dan artikulasi lebih tinggi hasil belajarnya dibandingkan dengan pembelajaran konvensional. Dengan demikian $\mathrm{H}_{\mathrm{a}}$ diterima dan $\mathrm{H}_{0}$ ditolak, sehingga dapat disimpulkan bahwa terdapat pengaruh yang signifikan antara penggunaan model pembelajaran TSTS, artikulasi dan konvensional terhadap hasil belajar siswa dalam proses pembelajaran biologi siswa pada materi ekosistem di kelas X SMA Negeri 1 Sibabangun Kabupaten Tapanuli Tengah.

Hal ini sesuai dengan penelitian dilakukan oleh Daulay (2014), dimana dalam hasil penelitiannya menyatakan bahwa hasil belajar yang dibelajarkan dengan model pembelajaran kooperatif tipe Two Stay Two Stray (TSTS) lebih

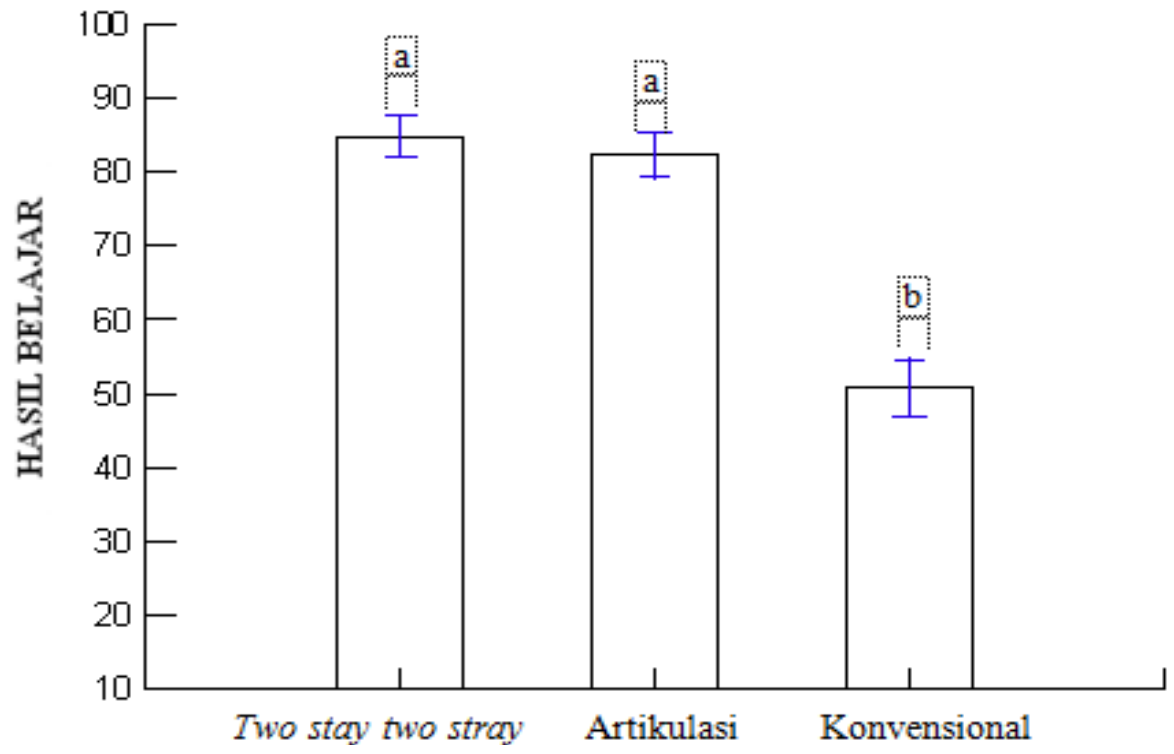

Gambar.1 Pengaruh Model Pembelajaran terhadap Hasil Belajar Siswa Kelas X SMA Negeri 1 Sibabangun Kabupaten Tapanuli Tengah. 
tinggi dibandingkan dengan hasil belajar yang dibelajarkan dengan dengan model pembelajaran kooperatif tipe Learning Together (LT) dan konvensional. Ismawati (2011), juga menyatakan bahwa model pembelajaran kooperatif Tipe Two Stay Two Stray (TSTS) pada pembelajaran Fisika dapat meningkatkan hasil belajar kognitif siswa dan diperkuat dengan hasil penelitian yang dilakukan oleh Sagala (2011).

Hasil penelitian yang dilakukan oleh Wahyuni (2011), menyimpulkan bahwa model pembelajaran kooperatif tipe TSTS dapat meningkatkan keaktifan siswa dalam proses pembelajaran. Apabila siswa ikut berpartisipasi aktif dalam kegiatan belajar mengajar, maka akan timbul interaksi positif antar siswa dan antara guru dengan siswa, sehingga iklim pembelajaran di kelas menjadi kondusif. Hal ini sesuai dengan pendapat Jones, K.A \& Jennifer L (2008), yang menyatakan bahwa dalam pembelajaran kooperatif ada keyakinan anggota kelompok bahwa kesuksesan kelompok tergantung pada kontribusi, inklusi dan kesuksesan masing-masing individu dalam kelompok. Faishal Mirza dalam Wardhani (2012), menyatakan bahwa model pembelajaran ini dapat meningkatkan kelima unsur proses pembelajaran kooperatif yang terdiri dari : saling ketergantungan positif, tanggung jawab perseorangan, tatap muka, komunikasi antar kelompok dan evaluasi proses kelompok.

Dengan demikian, berdasarkan penelitian yang telah dilakukan, bahwa hasil belajar dengan model pembelajaran kooperatif tipe Two Stay Two Stray (TSTS) lebih tinggi dibandingkan dengan model kooperatif tipe artikulasi dan konvensional.

Meskipun dalam penelitian ini diperoleh data bahwa hasil belajar dengan menggunakan model pembelajaran TSTS lebih tinggi dibandingkan dengan model pembelajaran artikulasi namun dalam proses pelaksanaan kedua model pembelajaran ini secara umum dapat meningkatkan rata-rata hasil belajar biologi siswa SMA Negeri 1 Sibabangun Kabupaten Tapanuli Tengah pada materi "ekosistem" dibandingkan dengan pembelajaran konvensional.

\section{PENUTUP}

\section{Simpulan}

Berdasarkan hasil-hasil temuan penelitian dan analisis yang telah dilakukan oleh peneliti, maka diperoleh simpulan bahwa terdapat pengaruh signifikan model pembelajaran kooperatif tipe Two Stay Two Stray (TSTS), artikulasi dan konvensional terhadap hasil belajar biologi siswa pada materi ekosistem kelas pada $\mathrm{X}$ SMA Negeri 1 Sibabangun Kabupaten Tapanuli Tengah. Hasil belajar siswa yang dibelajarkan dengan model pembelajaran Two Stay Two Stray (TSTS) dengan nilai rata-rata 84,71 lebih tinggi dibandingkan dengan hasil belajar siswa yang dibelajarkan dengan model pembelajaran artikulasi dengan nilai rata-rata 82,29 dan pembelajaran konvensional dengan nilai rata-rata 50,70 .

\section{REFERENSI}

Daulay, K. 2014. Pengaruh Model Pembelajaran Terhadap Hasil Belajar Biologi dan Kecakapan Sosial Siswa SMA Negeri 1 Batangonang Kab. Padanglawas Utara.Tesis tidak dipublikasikan.Program Pascasarjana Universitas Negeri Medan

Handayani, M. 2014. Pengaruh Model Pembelajaran Kooperatif Tipe Two Stay Two Stray Terhadap Pemahaman Konsep Matematis Siswa. Pendidikan Matematika, 3 (1): 56-60.

Ismawati, N., Hindarto, N. 2011. Penerapan Model Pembelajaran Kooperatif Dengan Pendekatan Struktural Two Stay Two Stray Untuk Meningkatkan Hasil Belajar Siswa Kelas X SMA. Jurnal Pendidikan Fisika Indonesia 7 : 38-41.

Jones, K.A. \& Jennifer, L. 2008. Making cooperative Learning Work in the Collage Classroo: An Application of the 'Five Pillars' of Cooperative Learning to Post-Secondary Instruction. Journal of Effective Teaching. 8 (2): 61-76.

Leluhur, W. 2009. Peningkatan Prestasi Belajar Siswa melalui Cooperative Learning Model Artikulasi dan Evaluasi bentuk Multiplechoice Mata Pelajaran IPS pada Siswa Kelas VIII C SMP Negeri I Licin Semester II Tahun Pelajaran 2008/2009. Jurnal Ilmiah Progressif, 17 (6): 45-64

Pasal 1 ayat 1 UU sistem Pendidikan Nasional Nomor 20 Tahun 2003.

Putra, I P.G.Y., Desak P,P., I Dewa, K,T. Pengaruh Model Pembelajaran TSTS Berbantuan Teknik Kancing Gemerincing Terhadap 
Hasil Belajar Siswa Pada Mata Pelajaran Pkn Kelas IV. Jurnal Mimbar PGSD Universitas Pendidikan Ganesha Jurusan PGSD, 2 (1): Tahun 2014.

Rachmawan, A.I., Nur, K. 2013. Perbedaan Hasil Belajar Siswa menggunakan Model Pembelajaran Kooperatif Tipe Artikulasi dengan Tipe Explicit Instruction pada Standar Kompetensi menggunakan Hasil Pengukuran Listrik di SMK Negeri 2 Surabaya. Jurnal Pendidikan Teknik Elektro, 2 (2): 635-643.

Sagala, Y.S. 2012. Pengaruh Pembelajaran Kooperatif Tipe Jigsaw Terhadap Hasil Belajar IPA dan Kecakapan Sosial Siswa di SMK Negeri 2 Binjai. Tesis tidak dipublikasikan.Program Pascasarjana Universitas Negeri Medan.

Sanjaya, W. 2012. Perencanaan dan Desain Sistem Pembelajaran. Jakarta: Kencana Prenada Media Group.

Shoimin, A. 2014. Pembelajaran Inovatif dalam Kurikulum 2013.Yogyakarta : Ar-Ruzz Media.

Silvia, L., Sefna, R., K, Delsi. 2012. Pengaruh Penerapan Model Artikulasi Terhadap Pemahaman Konsep Matematis Siswa Kelas IX SMPN 1 Sasak Ranah Pasisie Tahun Pelajaran 2012/2013. STKIP PGRI SUMBAR.

Wahyuni, S. 2011. Penerapan Model Pembelajaran Two Stay Two Stay sebagai Upaya Meningkatkan Keaktifan Siswa. Surakarta: Universitas Muhamadiyah Surakarta.

Wardhani, I.M., Sajidan., Maridi. 2012. Penerapan Model Pembelajaran Kooperatif Tipe Two Stay Two Stray disertai Audio-visual untuk Meningkatkan Kualitas Pembelajaran Biologi Siswa Kelas XI IPA SMA Negeri 7 Surakarta Tahun Pelajaran 2011/2012. Jurnal Pendidikan Biologi, 4 (1): 40-55 